Metals and Ceramics Division

\title{
DETERMINATION OF CHANNELING PERSPECTIVES FOR COMPLEX CRYSTAL STRUCTURES
}

W. R. Allen

Date Published: March 1993

NOTICE: This document contains information of a preliminary nature. It is subject to revision or correction and therefore does not represent a final report.

Prepared for the

DOE Office of Basic Energy Sciences

KC 0201040

Prepared by the

OAK RIDGE NATIONAL LABORATORY

Oak Ridge, Tennessee 37831-6285

managed by

MARTIN MARIETTA ENERGY SYSTEMS, INC.

for the

U.S. DEPARTMENT OF ENERGY under contract DE-AC05-84OR21400 


\section{CONTENTS}

LIST OF FIGURES

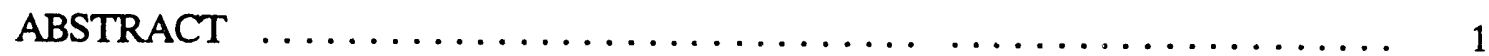

1. INTRODUCTION $\ldots \ldots \ldots \ldots \ldots \ldots \ldots \ldots \ldots \ldots \ldots \ldots \ldots \ldots$

2. COORDINATE SYSTEM MANIPULATION $\ldots \ldots \ldots \ldots \ldots \ldots \ldots \ldots$

3. SPINEL: CRYSTAL STRUCTURE AND CHANNELING PERSPECTIVES

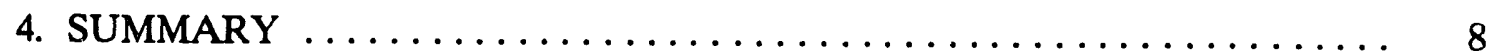

5. ACKNOWLEDGMENTS $\ldots \ldots \ldots \ldots \ldots \ldots \ldots \ldots \ldots \ldots \ldots \ldots \ldots$

6. REFERENCES $\ldots \ldots \ldots \ldots \ldots \ldots \ldots \ldots \ldots \ldots \ldots \ldots \ldots \ldots \ldots \ldots$

APPENDIX A. COMPUTER PROGRAM FOR FCC STRUCTURE . . . . . 11

APPENDIX B. COMPUTER PROGRAM FOR SPINEL STRUCTURE . . . . 15

APPENDIX C. COMPUTER PROGRAM SECTION LISTING

ATOM POSITIONS IN SPINEL .............. 23 


\section{LIST OF FIGURES}

Figure $\quad \underline{\text { Page }}$

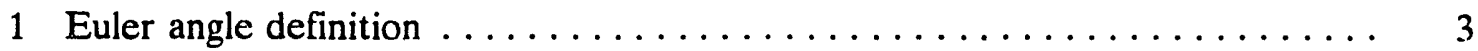

2 Channeling perspective for the $<100>$ axis of spinel $\ldots \ldots \ldots \ldots \ldots \ldots$

3 Channeling perspective for the $<110>$ axis of spinel $\ldots \ldots \ldots \ldots \ldots \ldots$

4 Channeling perspective for the $<111>$ axis of spinel $\ldots \ldots \ldots \ldots \ldots \ldots$

5 Channeling perspective for planes of spinel $\ldots \ldots \ldots \ldots \ldots \ldots \ldots \ldots$ 


\title{
DETERMINATION OF CHANNELING PERSPECTIVES FOR COMPLEX CRYSTAL STRUCTURES*
}

\author{
W. R. Allen
}

\begin{abstract}
Specification of the atomic arrangement for axes and planes of high symmetry is essential for crystal alignment using Rutherford backscattering and for studies of the lattice location of impurities in single crystals. By rotation of an inscribed orthogonal coordinate system, a visual image for a given perspective of a crystal structure can be specified. Knowledge of the atomic arrangement permits qualitative channeling perspectives to be visualized and calculation of continuum potentials for channeling. Channeling angular-yield profiles can then be analytically modeled and, subsequently, shadowing by host atoms of positions within the unit cell predicted. Software to calculate transformed atom positions for a channeling perspective in a single crystal will be described and illustrated for the spinel crystal structure.
\end{abstract}

\section{INTRODUCTION}

The interpretation of the angular dependence of ion channeling relies upon accurate identification of crystalline axes and planes. Converging at an axis of high symmetry are several low-index planes. Among other factors, axis identification in a channeling experiment depends upon the number and relative scattering yield of intersecting planes. A specific plane is identified with the assistance of stereographic projections and knowledge of interplanar spacings. Details of channeling in simple cubic and hexagonal crystal structures are given in ref. 1.

Theoretical modeling of ion channeling depends upon accurate knowledge of geometrical (i.e., visual) perspectives for axes and planes. For axes, the spacing between axial strings and linear atomic density and, for planes, the interplanar spacing and areal atomic density, can be calculated with the aid of a simple algorithm. From this information, lattice continuum potentials can be calculated that permit analytical calculations of channeling angular yield profiles. One important application is the qualitative and quantitative identification of a lattice site for an impurity species within the unit cell.

Although the process is almost trivial for simple cubic crystals, visualization of channeling perspectives for crystals with complex unit cells is, at best, difficult. The calculation of geometrical perspectives for axial and planar ion channeling in a complicated crystal structure will be illustrated with magnesium aluminate spinel $\left(\mathrm{MgAl}_{2} \mathrm{O}_{4}\right)$. One unit cell in the spinel

*Research sponsored by the Division of Materials Sciences, U.S. Department of Energy, under contract DE-AC05-84OR21400 with Martin Marietta Energy Systems, Inc. 
crystal structure of $\mathrm{MgAl}_{2} \mathrm{O}_{4}$ contains 56 atoms. A computer code will be presented that can be used to calculate atomic positions following rotation(s) of an inscribed Cartesian coordinate system.

\section{COORDINATE SYSTEM MANIPULATION}

A perspective parallel to a specific crystallographic axis can be obtained by an orthogonal transformation of the Cartesian coordinates of atomic positions within the unit cell. A simple rotation of the coordinate system can make the transformed $x$-axis coincide with the axial direction. The familiar elements of the $3 \times 3$ proper, orthogonal transformation matrix $A$ described in terms of the Euler angles $\alpha, \beta$, and $\gamma$ are: ${ }^{2}$

$$
\begin{aligned}
& A_{11}=\cos \gamma \cos \beta \cos \alpha-\sin \gamma \sin \alpha, \\
& A_{12}=\cos \gamma \cos \beta \sin \alpha+\sin \gamma \cos \alpha, \\
& A_{13}=-\cos \gamma \sin \beta, \\
& A_{21}=-\sin \gamma \cos \beta \cos \alpha-\cos \gamma \sin \alpha, \\
& A_{22}=-\sin \gamma \cos \beta \sin \alpha+\cos \gamma \cos \alpha, \\
& A_{23}=\sin \gamma \sin \beta, \\
& A_{31}=\sin \beta \cos \alpha, \\
& A_{32}=\sin \beta \sin \alpha, \text { and } \\
& A_{33}=\cos \beta .
\end{aligned}
$$

References 2 and 3 can be consulted for further details and figures defining the transformation employing the set of Euler angles. This definition of the axes and sequence of rotation for specifying the Euler angles is known as the $y$-convention. ${ }^{3}$ Figure 1 illustrates the definition of the set of Euler angles and the associated axis of rotation for each.

A computer program has been coded in Microsoft QuickBASIC version 4.5 to perform the orthogonal transformation to produce a channeling perspective for a given crystallographic direction. A listing of the program is presented in Appendices $\mathrm{A}, \mathrm{B}$, and $\mathrm{C}$. The transformation matrix $\mathbf{A}$ is applied to the vectors defined by the coordinate system origin and the Cartesian coordinates of each atom within a unit cell. Transformed atomic positions are projected onto the $\mathrm{Y}-\mathrm{Z}$ plane normal to the crystallographic direction to produce a channeling perspective for the crystal axis. In other words, the crystallographic axis is rotated such that it coincides with the $\mathrm{X}^{\prime}$-coordinate axis. Atom positions are sorted to eliminate duplicity in coordinates. Atomic spacing within each individual atomic string can also be obtained from the calculated X-positions normal to the $\mathrm{Y}-\mathrm{Z}$ plane. An accurate determination for a complex unit cell requires that atom positions in neighboring unit cells be included so that the atom sequencing in each string is correct and complete. Such a process was required in the program listed in Appendix B. Transformed Cartesian coordinates are written to an ASCII file and subsequently loaded into a technical graphics package (SigmaPlot 5.0 by Jandel Scientific) for display. Any commercial graphics package capable of importing ASCII text files or link graphics subroutines directly to the program could be optionally employed. Another enhancement would be to perform the transformation interactively and display the channeling perspective in live time on the computer video display. Although illustrated only for cubic lattice structures, the code can be simply modified to calculate channeling perspectives for any crystal structure. 
ORNL-DWG 92-11926
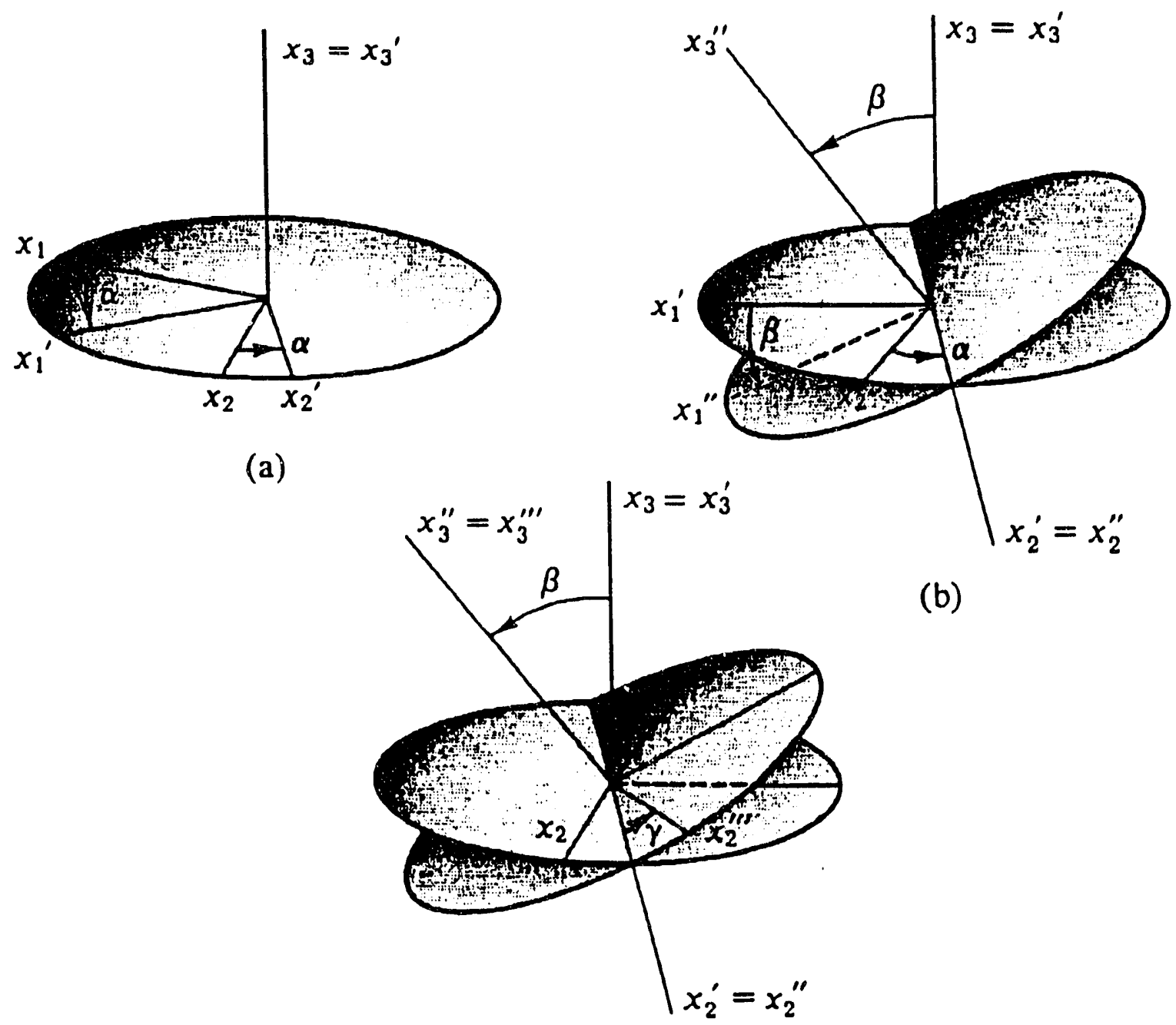

(b)

(c)

Fig. 1. Schematic diagrams defining the three Euler angles as described by the $y$-convention. 
The rotation(s) necessary to obtain the atomic configuration for a given geometrical perspective are easily calculated. The angle $\phi$ between two crystal planes $\left(h_{1}, k_{1}, l_{1}\right)$ and $\left(h_{2}, k_{2}, l_{2}\right)$ for a cubic space lattice is given by the following equation:

$$
\cos \phi=\frac{h_{1} h_{2}+k_{1} k_{2}+l_{1} l_{2}}{\sqrt{\left(h_{1}{ }^{2}+k_{1}{ }^{2}+l_{1}{ }^{2}\right)\left(h_{2}{ }^{2}+k_{2}{ }^{2}+l_{2}{ }^{2}\right)}}
$$

Equations to determine angular separation between planes in other crystal structures can be found in ref. 4. Spherical geometry is used to determine the individual rotation angles required to create a given channeling perspective. For example, a $45^{\circ}$ rotation about the vertical $\mathrm{Z}$-axis transforms a (100) perspective for spinel (or any cubic crystal structure) into a (110) perspective. An additional $35.26^{\circ}$ rotation of the $Z$-axis about the rotated $X$-axis will transform a (110) perspective for spinel into a (111) perspective. Appendix A contains a simple code that calculates atom positions following rotation for a face-centered-cubic (fcc) lattice structure. This is provided as a check of the validity of the algorithm. Determination of channeling perspectives for the spinel crystal structure (as coded in Appendices $\mathrm{B}$ and $\mathrm{C}$ ) will be illustrated for $\mathrm{MgAl}_{2} \mathrm{O}_{4}$ in Sect. 3.

\section{SPINEL: CRYSTAL STRUCTURE AND CHANNELING PERSPECTIVES}

The spinel structure (space group $\mathrm{Fd} 3 \mathrm{~m}$ ) of $\mathrm{MgAl}_{2} \mathrm{O}_{4}$ has a framework of oxygen anions in nearly perfect fcc close-packing., (The slight displacement of anions will be ignored in ensuing discussions.) Anion layers are stacked in an A,B,C,A fashion with cations lying in the interstices. Each $\mathrm{Al}$ cation is octahedrally surrounded by six anions and each $\mathrm{Mg}$ cation by four tetrahedrally distributed anions. A single unit cell of natural $\mathrm{MgAl}_{2} \mathrm{O}_{4}\left(a_{0}=0.808 \mathrm{~nm}\right)$ contains 32 anions, $16 \mathrm{Al}$ cations, and $8 \mathrm{Mg}$ cations. The 16 octahedral and 56 tetrahedral interstices that are intrinsically unfilled will be described in this study by the term "vacant". The unit cell can be sectioned into eight subcells of two equiprobable, distinct varieties-Types I and II. These are ordered such that the six nearest-neighbor subcells adjoining the cube faces of a subcell are of the opposite type (see ref. 5 for further details).

A channeling perspective for the $<100>$ axis of $\mathrm{MgAl}_{2} \mathrm{O}_{4}$ is displayed in Fig. 2. Axial strings of anions and $\mathrm{Al}$ cations shield all vacant octahedral interstices. Axial strings of $\mathrm{Mg}$ cations incorporate three out of seven vacant tetrahedral interstices. The remaining vacant tetrahedral interstices are unshielded by host atoms, and resident impurity atoms would be visible to channeled analysis ions. Four distinct varieties of axial strings are present for a $<110>$ axial channeling perspe tive of $\mathrm{MgAl}_{2} \mathrm{O}_{4}$, shown in Fig. 3. Anions exclusively populate one type of axial string. Aluminum cations constitute two axial string types, one in which alternating octahedral interstices are vacant. Magnesium cations alternate with vacant tetrahedral interstices in the fourth type of axial string. Six out of seven vacant tetrahedral interstices and one-half of the vacant octahedral interstices are unshielded by host atoms. A channeling perspective for the $<111>$ axis of $\mathrm{MgAl}_{2} \mathrm{O}_{4}$ is shown in Fig. 4. All axial strings contain Al cations and anions with a minority fraction incorporating $\mathrm{Mg}$ cations. Since all vacant octahedral and tetrahedral 


\section{$<100>$ AXIS}
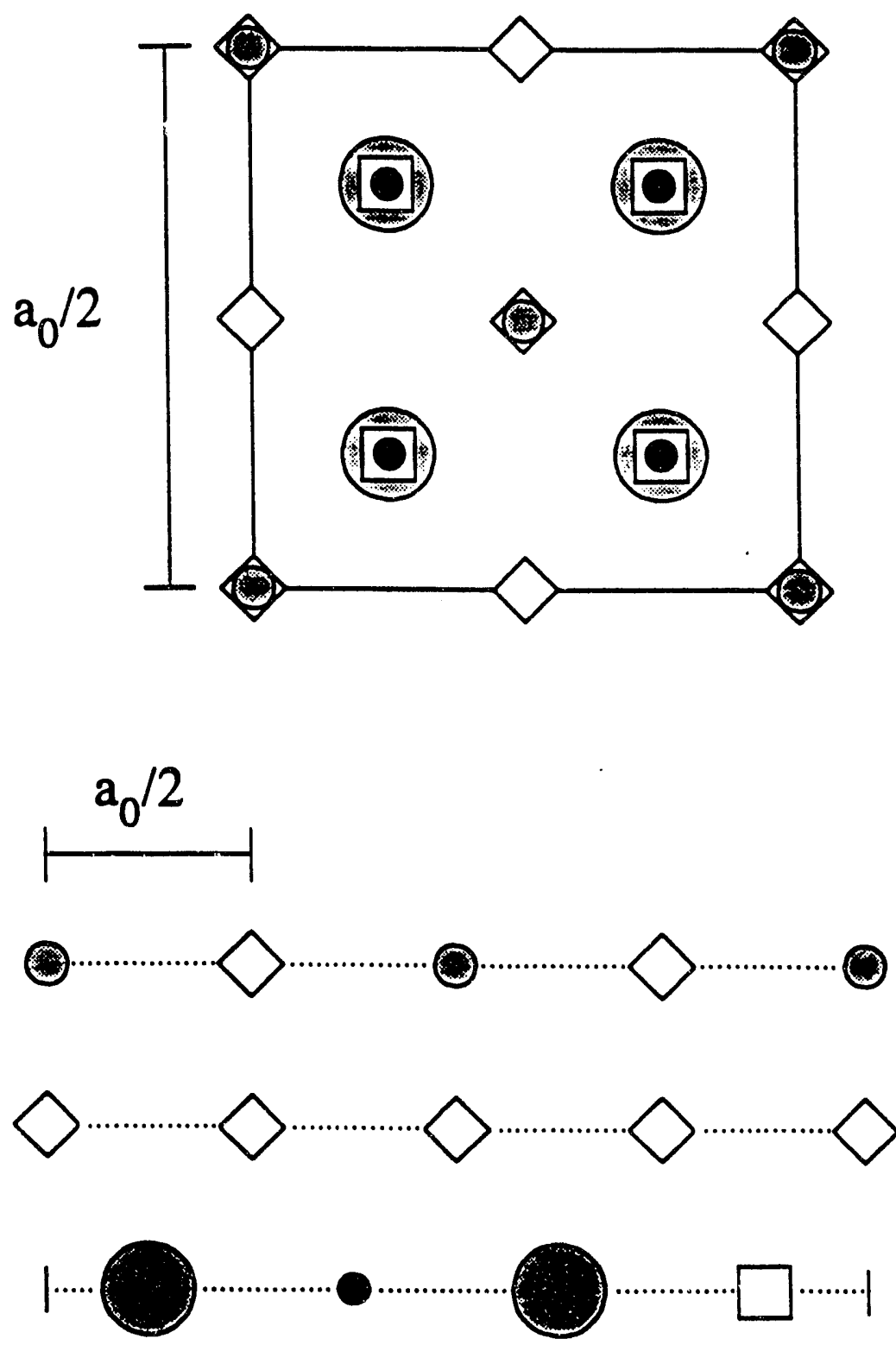

Fig. 2. Atomic arrangement for $\mathrm{MgAl}_{2} \mathrm{O}_{4}$ from a perspective parallel to the $<100\rangle$ axis (upper) and end-views indicating the interatomic spacing for each constituent string type. Oxygen anions, $\mathrm{Al}$ cations, and $\mathrm{Mg}$ cations are represented by large shaded circles, small solid circles, and small shaded circles, respectively. Vacant octahedral and tetrahedral interstices are denoted by open squares and diamonds, respectively. 


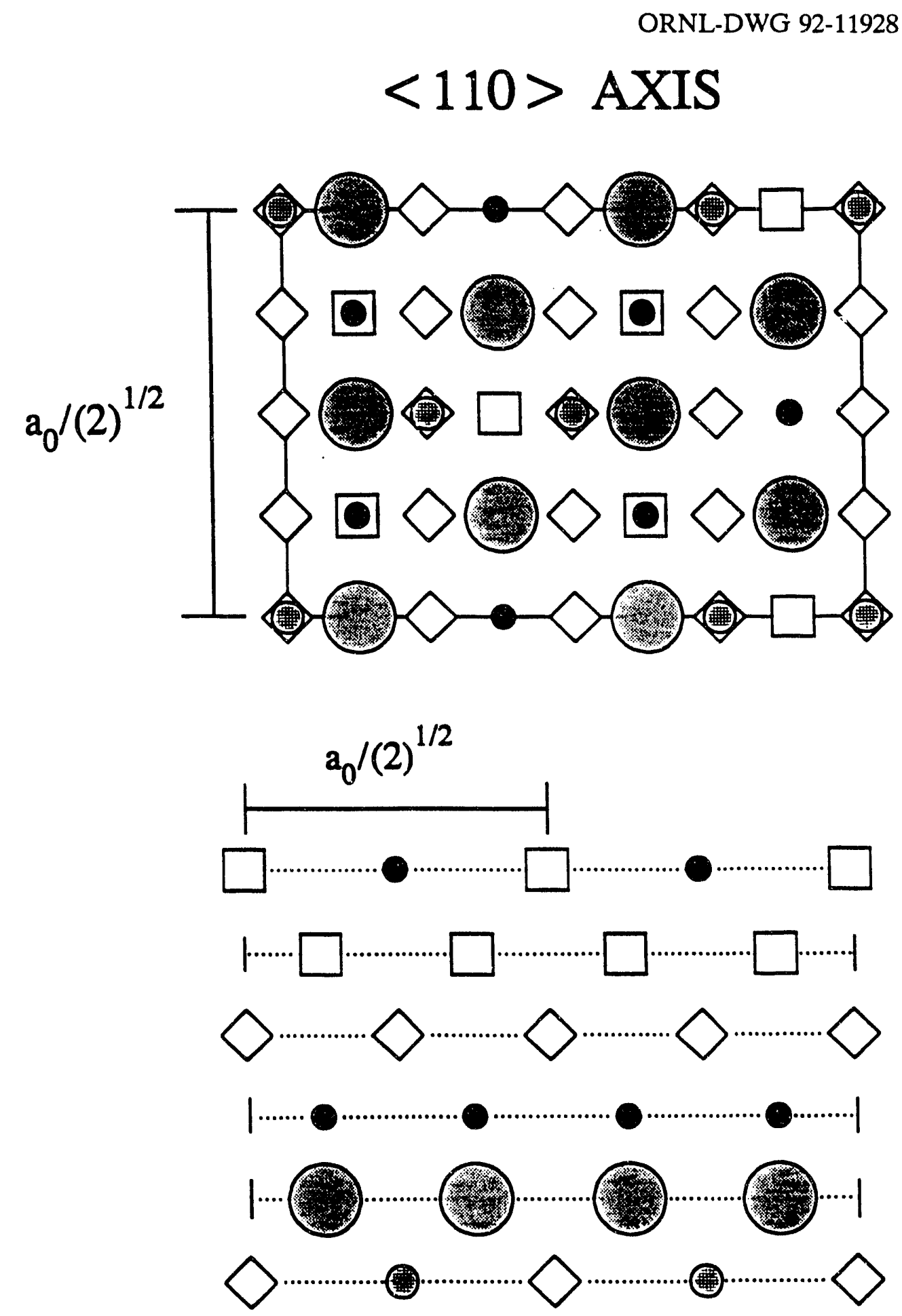

Fig. 3. Atomic arrangement for $\mathrm{MgAl}_{2} \mathrm{O}_{4}$ from a perspective parallel to the $\langle 110\rangle$ axis (upper) and end-views indicating the interatomic spacing for each constituent string type (symbolism as in Fig. 1). 
ORNL-DWG 92-1.1929

\section{$<111>$ AXIS}
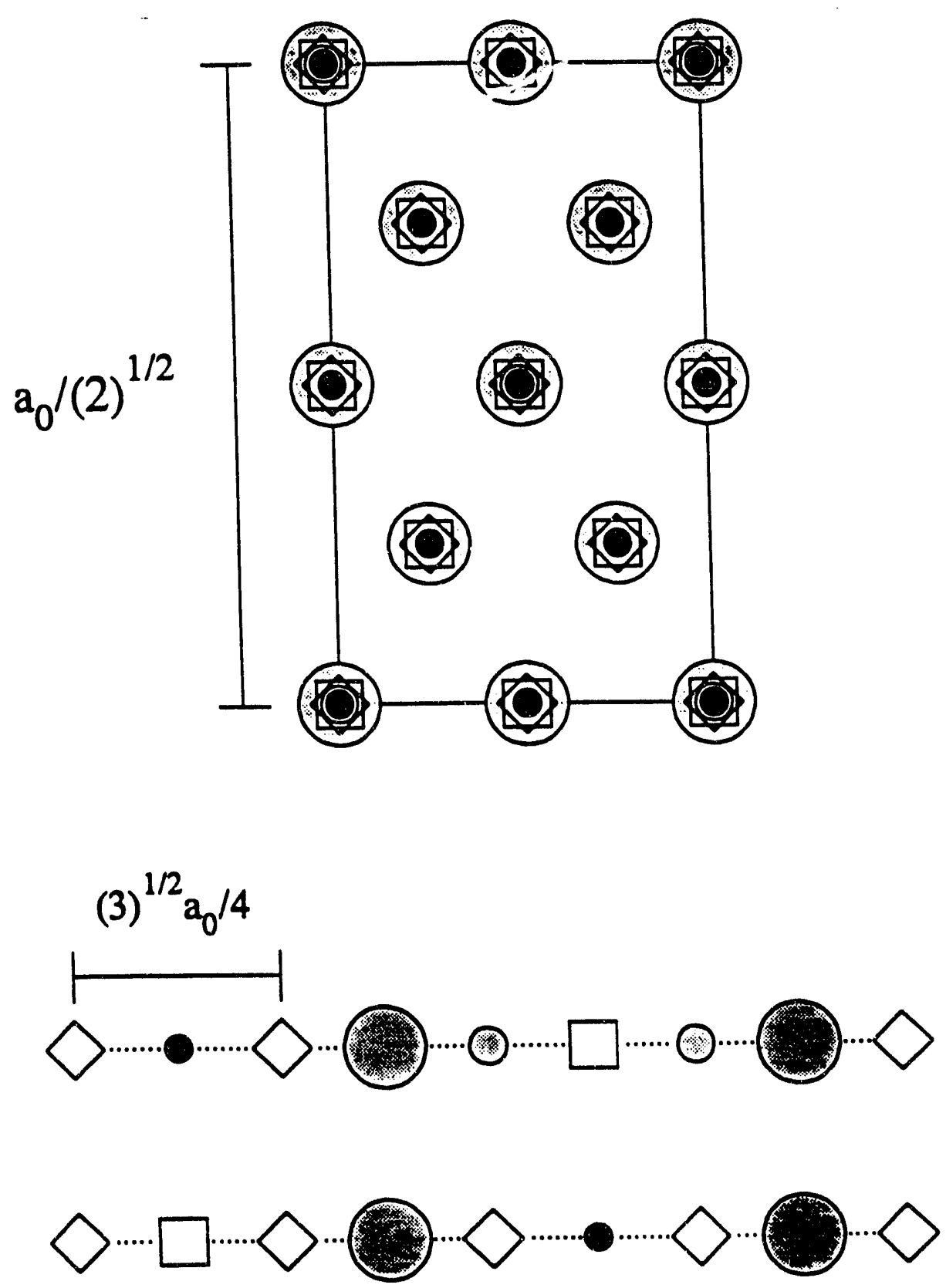

Fig. 4. Atomic arrangement for $\mathrm{MgAl}_{2} \mathrm{O}_{4}$ from a perspective parallel to the $\langle 111\rangle$ axis (upper) and end-views indicating the interatomic spacing for each constituent string type (symbolism as in Fig. 1). 
interstices are collinear with the axial strings, impurity atoms in these positions would be shielded for $<111>$ axial channeling.

Figure 5 schematically displays the atomic configurations and populations of vacant interstices for the major high-symmetry planes of $\mathrm{MgAl}_{2} \mathrm{O}_{4}$. Mixed atomic sheets of anions and $\mathrm{Al}$ cations that alternately incorporate $\mathrm{Mg}$ cations constitute the (110) plane. Mixed atomic sheets of anions and $\mathrm{Al}$ cations alternate with pure atomic sheets of $\mathrm{Mg}$ cations to form the (100) plane. All atomic sheets of the (211) plane contain anions and Al cations. Alternating atomic sheets incorporate $\mathrm{Mg}$ cations. For these three planes, all vacant octahedral and tetrahedral interstices are coplanar with the atomic sheets and are shielded by host atoms. Atomic sheets of the (111) plane contain a single element. All vacant octahedral interstices and three out of seven vacant tetrahedral interstices are shielded for (111) planar channeling.

Above $1100 \mathrm{~K}$ in natural $\mathrm{MgAl}_{2} \mathrm{O}_{4}$, or at any temperature in synthetic $\mathrm{MgAl}_{2} \mathrm{O}_{4}$, cations randomly populate the permitted (i.e., stoichiometrically correct) interstices. ${ }^{7}$ In this inverse spinel structure, up to one-half of the Al cations occupy tetrahedrally coordinated interstices, and the remainder share the octahedrally coordinated interstices with $\mathrm{Mg}$ cations. Although cations are shuffled in the interstices, the crystal structure remains intact.

\section{SUMMARY}

A computer program has been developed herein to aid in the determination of geometrical perspectives of use in ion channeling. For a complex crystal structure such as spinel, computer assistance is required to obtain accurate channeling perspectives.

\section{ACKNOWLEDGMENTS}

The author would like to thank M. W. Terrell and M. L. Hodges for report preparation final make-up and composition, respectively, and K. Spence for editing. 
ORNL-DWG 92-11930

OCTAHEDRAL

(110)

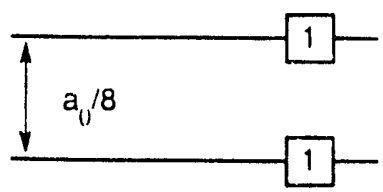

TETRAHEDRAL

$\mathrm{Al}+\mathrm{O}[2]$

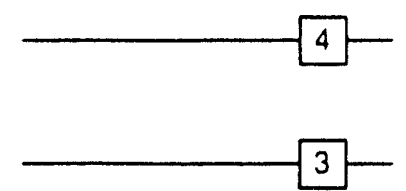

(100)
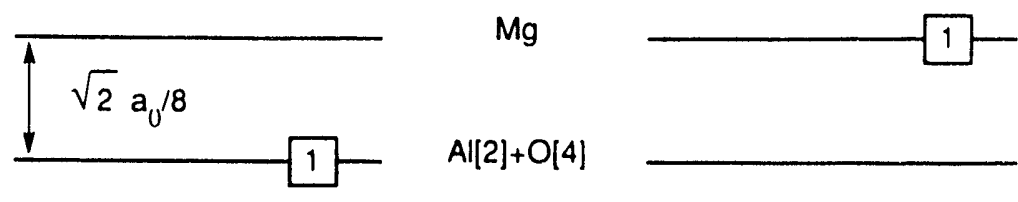

$\mathrm{Al}[2]+\mathrm{O}[4]$

(211)

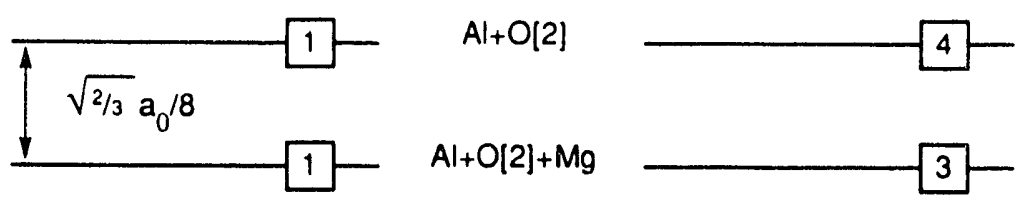

111)

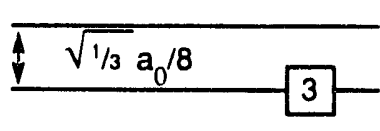

$M g$

Al

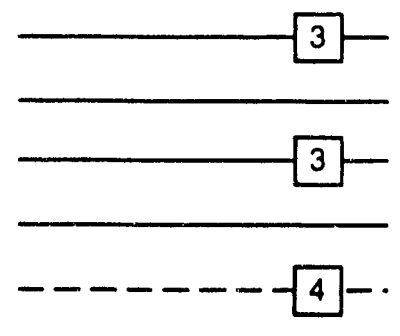

$\mathrm{Mg}$
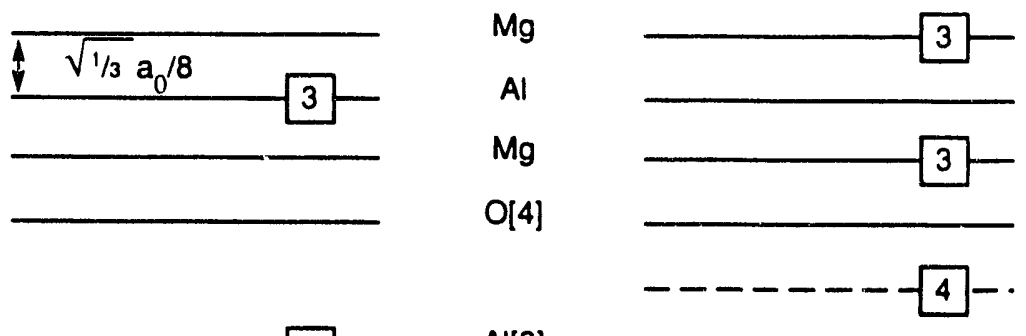

$\mathrm{O}[4]$
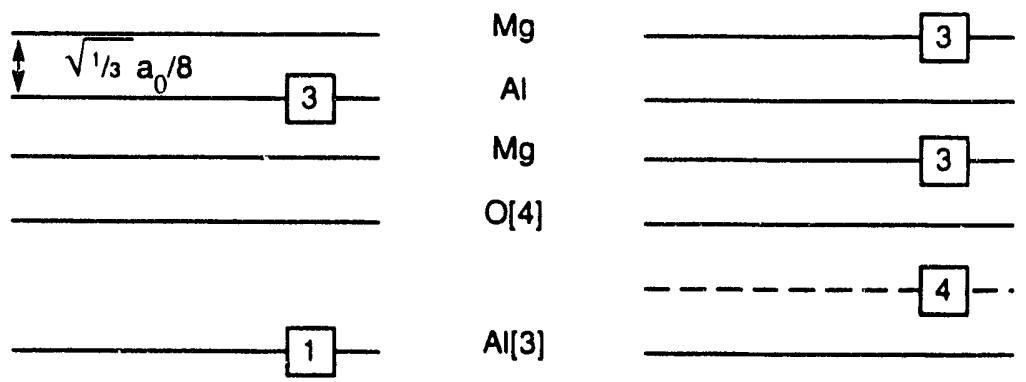

Al[3]

O[4]

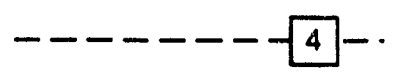

Fig. 5. Schematic of major crystal planes for $\mathrm{MgAl}_{2} \mathrm{O}_{4}$. The numbers in the squares indicate the relative probability of occurrence for vacant octahedral and tetrahedral interstices in the atomic sheet. For example, one out of two vacant octahedral interstices are shielded by each type of atomic sheet for the (110) plane. The relative atomic population of each atomic sheet is bracketed beside each constituent element (a weight of unity if no number is listed). For example, the (110) plane consists of atomic sheets of two types. One type contains $\mathrm{Al}$ and $\mathrm{O}$ in a 1:2 ratio, and the second contains $\mathrm{Al}, \mathrm{O}$, and $\mathrm{Mg}$ in a 1:2:1 ratio. Interplanar spacings are given as a fraction of the lattice constant $a_{0}$. 


\section{REFERENCES}

1. B. R. Appleton and G. Foti, Chapter 4 in Ion Beam Handbook for Materials Analysis, ef. J. W. Mayer and E. Rimini, Academic Press, New York, 1977.

2. G. Arfken, Chapter 3 in Mathematical Methods for Physicists, Academic Press, New York, 1975.

3. H. Goldstein, Chapter 4 in Classical Mechanics, Addison-Wesley, Reading, Mass., 1980.

4. P. Hirsch, A. Howie, R. B. Nicholson, D. W. Pashley, and M. J. Whalen, Electron Microscopy of Thin Crystals, Appendix 9, Robert E. Kreiger, Malabar, Fla., 1977.

5. D. McKie and C. McKie, pp. 327-30 in Clystalline Solids, John Wiley, New York, 1974.

6. R. W. G. Wyckoff, pp. 75-76 in Crystal Structures, 2nd ed., Vol. 3, John Wiley, New York, 1965.

7. J. Hornstra, J. Phys. Chem. Solids 15, 311 (1960). 
APPENDIX A

COMPUTER PROGRAM FOR FCC STRUCTURE 
APPENDIX A

COMPUTER PROGRAM FOR FCC STRUCTURE

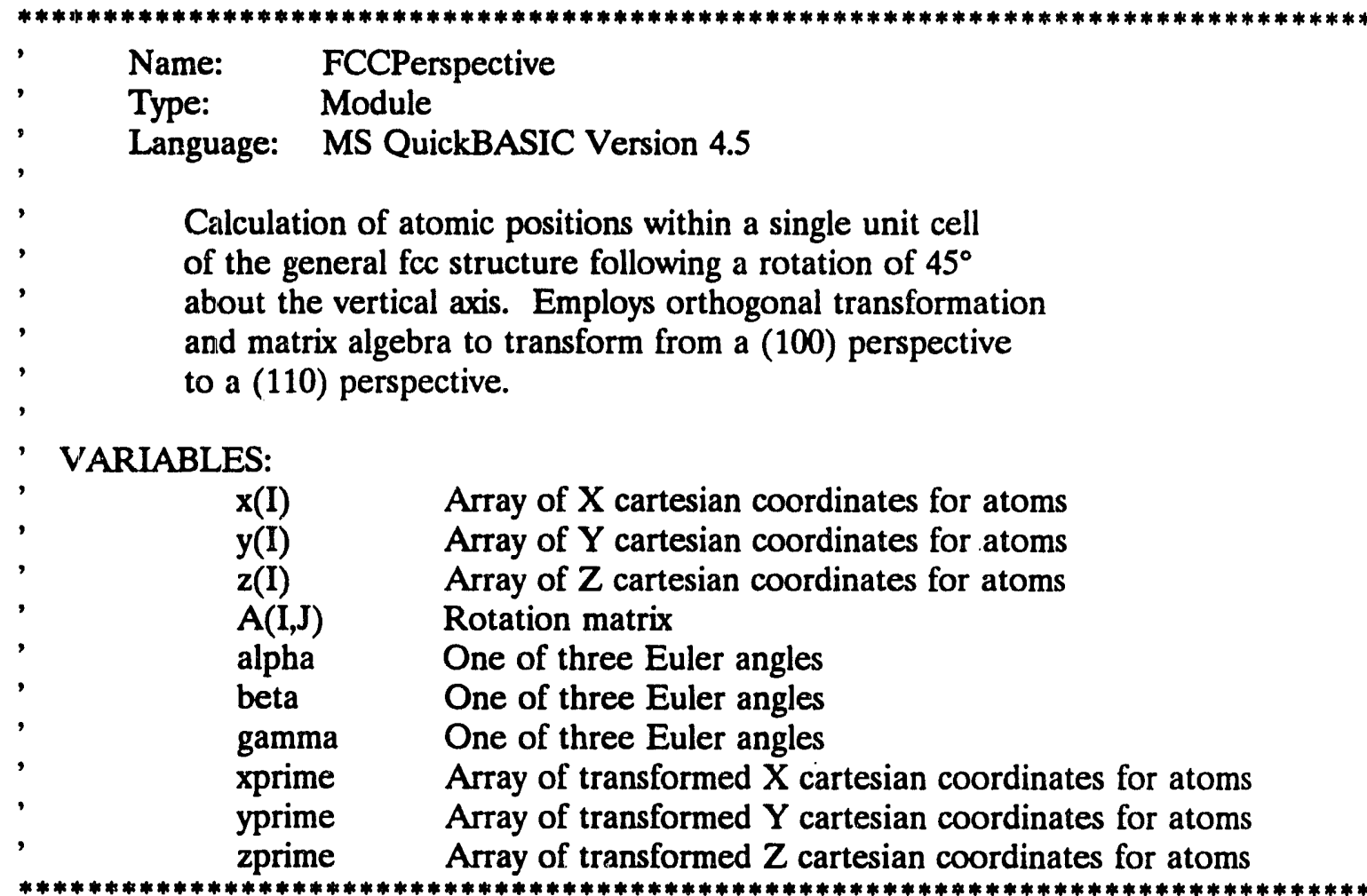

DIM x(14), y(14), $z(14), A(3,3)$

CONSTANT pi $=3.14159263539 \#$

' -- Cartesian coordinates of atoms within the unit cell of an fcc crystal.

$$
\begin{array}{lll}
x(1)=0: & y(1)=0: & z(1)=0 \\
x(2)=1: & y(2)=0: & z(2)=0 \\
x(3)=0: & y(3)=1: & z(3)=0 \\
x(4)=0: & y(4)=0: & z(4)=1 \\
x(5)=1: & y(5)=1: & z(5)=0 \\
x(6)=1: & y(6)=0: & z(6)=1 \\
x(7)=0: & y(7)=1: & z(7)=1 \\
x(8)=1: & y(8)=1: & z(8)=1 \\
x(9)=.5: & y(9)=.5: & z(9)=0 \\
x(10)=.5: & y(10)=0: & z(10)=.5 \\
x(11)=.5: & y(11)=.5: & z(11)=1 \\
x(12)=.5: & y(12)=1: & z(12)=.5 \\
x(13)=0: & y(13)=.5: z(13)=.5 \\
x(14)=1: & y(14)=.5: z(14)=.5
\end{array}
$$




$$
\begin{array}{ll}
\text { alpha }=45 ! * \text { pi } / 180 & , \text {-- Set of Euler angles to transform } \\
\text { beta }=0 ! & ,- \text { - from a }(100) \text { to a }(110) \\
\text { gamma }=0 ! & ,- \text { perspective in cubic crystal. }
\end{array}
$$

'-- Define the elements of the rotation matrix.

$$
\begin{aligned}
& A(1,1)=\operatorname{COS}(\text { gamma }) * \operatorname{COS}(\text { beta }) * \operatorname{COS}(\text { alpha })-\operatorname{SIN}(\text { gamma }) * \operatorname{SIN}(\text { alpha }) \\
& A(1,2)=\operatorname{COS}(\text { gamma) } * \operatorname{COS}(\text { beta) } * \operatorname{SIN}(\text { alpha })+\operatorname{SIN}(\text { gamma }) * \operatorname{COS}(\text { alpha }) \\
& \mathrm{A}(1,3)=-\operatorname{COS}(\text { gamma) } * \operatorname{SIN}(\text { beta }) \\
& \mathrm{A}(2,1)=-\operatorname{SIN}(\text { gamma }) * \operatorname{COS}(\text { beta) } * \operatorname{COS}(\text { alpha) }-\operatorname{COS} \text { (gamma) } * \operatorname{SIN}(\text { alpha }) \\
& A(2,2)=-\operatorname{SIN}(\text { gamma) } * \operatorname{COS}(\text { beta) } * \operatorname{SIN}(\text { alpha })+\operatorname{COS} \text { (gamma) } * \operatorname{COS}(\text { alpha) } \\
& A(2,3)=\operatorname{SIN}(\text { gamma }) * \operatorname{SIN}(\text { beta }) \\
& A(3,1)=\operatorname{SIN}(\text { beta }) * \operatorname{COS}(\text { alpha }) \\
& A(3,2)=\operatorname{SIN}(\text { beta }) * \operatorname{SIN}(\text { alpha }) \\
& A(3,3)=\operatorname{COS}(\text { beta })
\end{aligned}
$$

-- Define an ASCII text file (Plot41\$) to receive the transformed

' -- Cartesian coordinates of the atom positions.

Plot41\$ = "E:ATOMS.1"

OPEN Plot41\$ FOR OUTPUT AS \#4 LEN $=8$

' -- Perform rotation and indiscriminately output transformed coordinates

'.. to the ASCII file.

FOR I $=1$ TO 14

$$
\begin{aligned}
& \text { xprime }=A(1,1) * x(I)+A(1,2) * y(I)+A(1,3) * z(I) \\
& \text { yprime }=A(2,1) * x(I)+A(2,2) * y(I)+A(2,3) * z(I)
\end{aligned}
$$$$
\text { zprime }=A(3,1) * x(I)+A(3,2) * y(I)+A(3,3) * z(I)
$$

WRITE \#4, yprime, zprime

\section{NEXT I}

\section{CLOSE \#4}

END 
APPENDIX B

COMPUTER PROGRAM FOR SPINEL STRUCTURE 


\section{APPENDIX B}

\section{COMPUTER PROGRAM FOR SPINEL STRUCTURE}

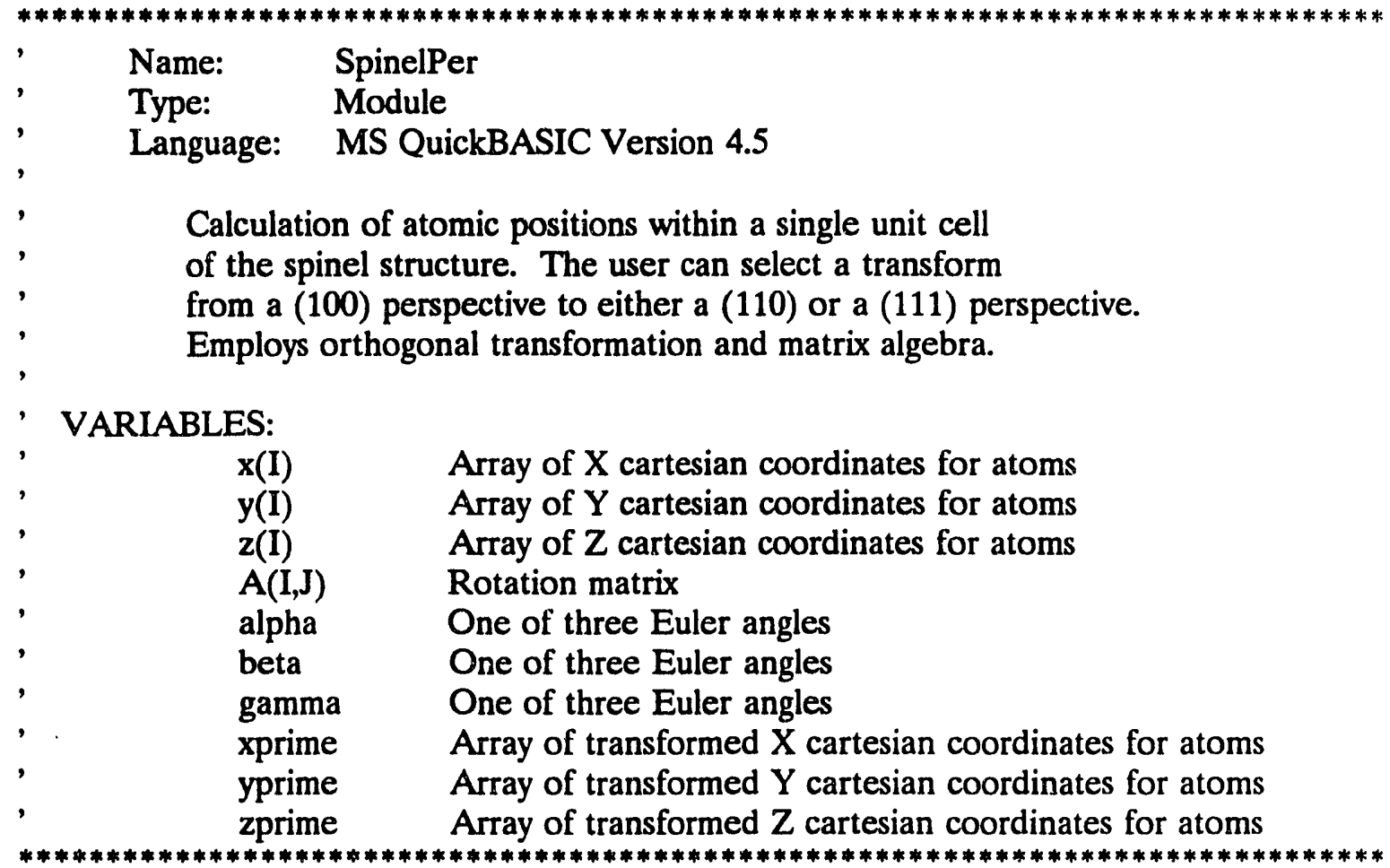

DIM x0(1700), y0(1700), z0(1700), A(3,3)

DIM xinc(30), yinc(30), zinc(30)

CONSTANT pi $=3.14159265359 \#$

'.- Copy the block of Cartesian coordinates for each atom or interstice

' -- from the master list in Appendix $C$ to the appropriate location below.

' -- Values are given as a multiple of the lattice spacing $a_{0}$.

' -- Magnesium cation positions - Type I sub-cell - chosen from master list

First $(1)=1:$ Last $(1)=4 \quad$ '. $(X 0, Y 0$, Z0) array subscript range

$\mathrm{x} 0(1)=0 \quad: \mathrm{y} 0(1)=0 \quad: \mathrm{z} 0(1)=0$

$\mathrm{x} 0(2)=0: \mathrm{y} 0(2)=1 / 2: \mathrm{zO}(2)=1 / 2$

$\mathrm{x} 0(3)=1 / 2: \mathrm{y} 0(3)=1, / 2: \mathrm{z0}(3)=0$

$\mathrm{x} 0(4)=1 / 2: \mathrm{y} 0(4)=0 \quad: \mathrm{z} 0(4)=1 / 2$

' -- Magnesium cation positions - Type II subcell - chosen from master list

First $(2)=36: \operatorname{Last}(2)=40 \quad$ '-- $(\mathrm{X} 0, \mathrm{Y0}, \mathrm{Z} 0)$ array subscript range 


$$
\begin{aligned}
& \mathrm{x} 0(36)=3 / 4: \mathrm{y} 0(36)=1 / 4: \mathrm{z} 0(36)=1 / 4 \\
& \mathrm{x} 0(37)=1 / 2: \mathrm{y} 0(37)=1 / 2: \mathrm{z} 0(37)=0 \\
& \mathrm{x} 0(38)=1 / 2: \mathrm{y} 0(38)=0 \quad: \mathrm{z} 0(38)=1 / 2 \\
& \mathrm{x} 0(39)=1: \mathrm{y} 0(39)=1 / 2: \mathrm{z} 0(39)=1 / 2 \\
& \mathrm{x} 0(40)=1: \mathrm{y} 0(40)=0 \quad: \mathrm{z} 0(40)=0
\end{aligned}
$$

'-- Array of increments for atomic positions $(x 0, y 0, z 0)$ to translate

' -- the initial unit cell to other relative locations without having to enter

' -- the coordinates of each separately. This enables the accurate

' -- determination of relative positions of atoms within the atomic strings

' -- without omitting any pertinent information. Values are given as a multiple

' - of the lattice spacing $a_{0}$. For example, $\operatorname{xinc}(2)=0: \operatorname{yinc}(2)=1: \operatorname{zinc}(2)=0$

' -- will result in the calculation of transformed atom positions in the unit cell

'-- displaced by $a_{0}$ along the Y-axis.

$$
\begin{aligned}
& \operatorname{xinc}(1)=0: \operatorname{yinc}(1)=0: \operatorname{zinc}(1)=0 \\
& \operatorname{xinc}(2)=0: \operatorname{yinc}(2)=1: \operatorname{zinc}(2)=0 \\
& \operatorname{xinc}(3)=0: \operatorname{yinc}(3)=-1: \operatorname{zinc}(3)=0 \\
& \operatorname{xinc}(4)=-1: \operatorname{yinc}(4)=0: \operatorname{zinc}(4)=0 \\
& \operatorname{xinc}(5)=1: \operatorname{yinc}(5)=0: \operatorname{zinc}(5)=0 \\
& \operatorname{xinc}(6)=1: \operatorname{yinc}(6)=1: \operatorname{zinc}(6)=0 \\
& \operatorname{xinc}(7)=-1: \operatorname{yinc}(7)=-1: \operatorname{zinc}(7)=0 \\
& \operatorname{xinc}(8)=1: \operatorname{yinc}(8)=-1: \operatorname{zinc}(8)=0 \\
& \operatorname{xinc}(9)=-1: \operatorname{yinc}(9)=1: \operatorname{zinc}(9)=0 \\
& \operatorname{xinc}(10)=0: \operatorname{yinc}(10)=0: \operatorname{zinc}(10)=1 \\
& \operatorname{xinc}(11)=1: \operatorname{yinc}(11)=1: \operatorname{zinc}(11)=1 \\
& \operatorname{xinc}(12)=0: \operatorname{yinc}(12)=1: \operatorname{zinc}(12)=1 \\
& \operatorname{xinc}(13)=1: \operatorname{yinc}(13)=0: \operatorname{zinc}(13)=1 \\
& \operatorname{xinc}(14)=-1: \operatorname{yinc}(14)=0: \operatorname{zinc}(14)=1 \\
& \operatorname{xinc}(15)=0: \operatorname{yinc}(15)=-1: \operatorname{zinc}(15)=1 \\
& \operatorname{xinc}(16)=0: \operatorname{yinc}(16)=0: \operatorname{zinc}(16)=-1 \\
& \operatorname{xinc}(17)=1: \operatorname{yinc}(17)=-1: \operatorname{zinc}(17)=-1 \\
& \operatorname{xinc}(18)=0: \operatorname{yinc}(18)=1: \operatorname{zinc}(18)=-1 \\
& \operatorname{xinc}(19)=1: \operatorname{yinc}(19)=0: \operatorname{zinc}(19)=-1 \\
& \operatorname{xinc}(20)=-1: \operatorname{yinc}(20)=0: \operatorname{zinc}(20)=-1 \\
& \operatorname{xinc}(21)=0: \operatorname{yinc}(21)=-1: \operatorname{zinc}(21)=-1 \\
& \operatorname{xinc}(22)=-1: \operatorname{yinc}(22)=-1: \operatorname{zinc}(22)=1 \\
& \operatorname{xinc}(23)=1: \operatorname{yinc}(23)=-1: \operatorname{zinc}(23)=1 \\
& \operatorname{xinc}(24)=-1: \operatorname{yinc}(24)=1: \operatorname{zinc}(24)=1 \\
& \operatorname{xinc}(25)=-1: \operatorname{yinc}(25)=-1: \operatorname{zinc}(25)=-1 \\
& \operatorname{xinc}(26)=1: \operatorname{yinc}(26)=-1: \operatorname{zinc}(26)=-1 \\
& \operatorname{xinc}(27)=-1: \operatorname{yinc}(27)=1: \operatorname{zinc}(27)=-1
\end{aligned}
$$

'-- Define the magnitudes of the Eulerian angles for a given rotation.

'.- Choose one of the sets of angles and enter on the line below.

, *** To produce a (111) perspective, choose

' alpha $=45 .{ }^{*}$ pi $/$ 180.: beta $=35.2644 * \mathrm{Pi} / 180 .:$ gamma $=0$ 
To produce a (110) perspective, choose

' alpha $=45 .{ }^{*}$ pi $/ 180 .:$ beta $=0:$ gamma $=0$

alpha $=45 ! *$ pi $/ 180 !$ : beta $=0:$ gamma $=0$

' -- Define the elements of the rotation matrix.

$A(1,1)=\operatorname{COS}($ gamma $) * \operatorname{COS}($ beta $) * \operatorname{COS}($ alpha $)-\operatorname{SIN}($ gamma $) * \operatorname{SIN}($ alpha $)$

$\mathrm{A}(1,2)=\operatorname{COS}($ gamma $) * \operatorname{COS}($ beta $) * \operatorname{SIN}($ alpha $)+\operatorname{SIN}($ gamma $) * \operatorname{COS}($ alpha $)$

$\mathrm{A}(1,3)=-\operatorname{COS}$ (gamma) * $\operatorname{SIN}($ beta $)$

$A(2,1)=-\operatorname{SIN}($ gamma $) * \operatorname{COS}($ beta $) * \operatorname{COS}($ alpha $)-\operatorname{COS}($ gamma $) * \operatorname{SIN}($ alpha $)$

$\mathrm{A}(2,2)=-\operatorname{SIN}($ gamma $) * \operatorname{COS}($ beta $) * \operatorname{SIN}($ alpha $)+\operatorname{COS}$ (gamma) * COS(alpha)

$\mathrm{A}(2,3)=\operatorname{SIN}($ gamma $) * \operatorname{SIN}($ beta $)$

$\mathrm{A}(3,1)=\operatorname{SIN}($ beta $) * \operatorname{COS}($ alpha $)$

$A(3,2)=\operatorname{SIN}($ beta $) * \operatorname{SIN}($ alpha $)$

$A(3,3)=\operatorname{COS}($ beta $)$

'-- Define an ASCII text file (Plot41\$) to receive the transformed

'.- Cartesian coordinates of the atom positions.

Plot41\$ = "E:ATOMS.1"

OPEN Plot41\$ FOR OUTPUT AS \#4 LEN $=8$

'-- 27 total translations of the initial unit cell given by the

'.- array xinc(), yinc(), zinc()

FOR K = 1 TO 27

'-- Calculations are done for 4 translations of the individual Type I subcell

'-- locations within the unit cell.

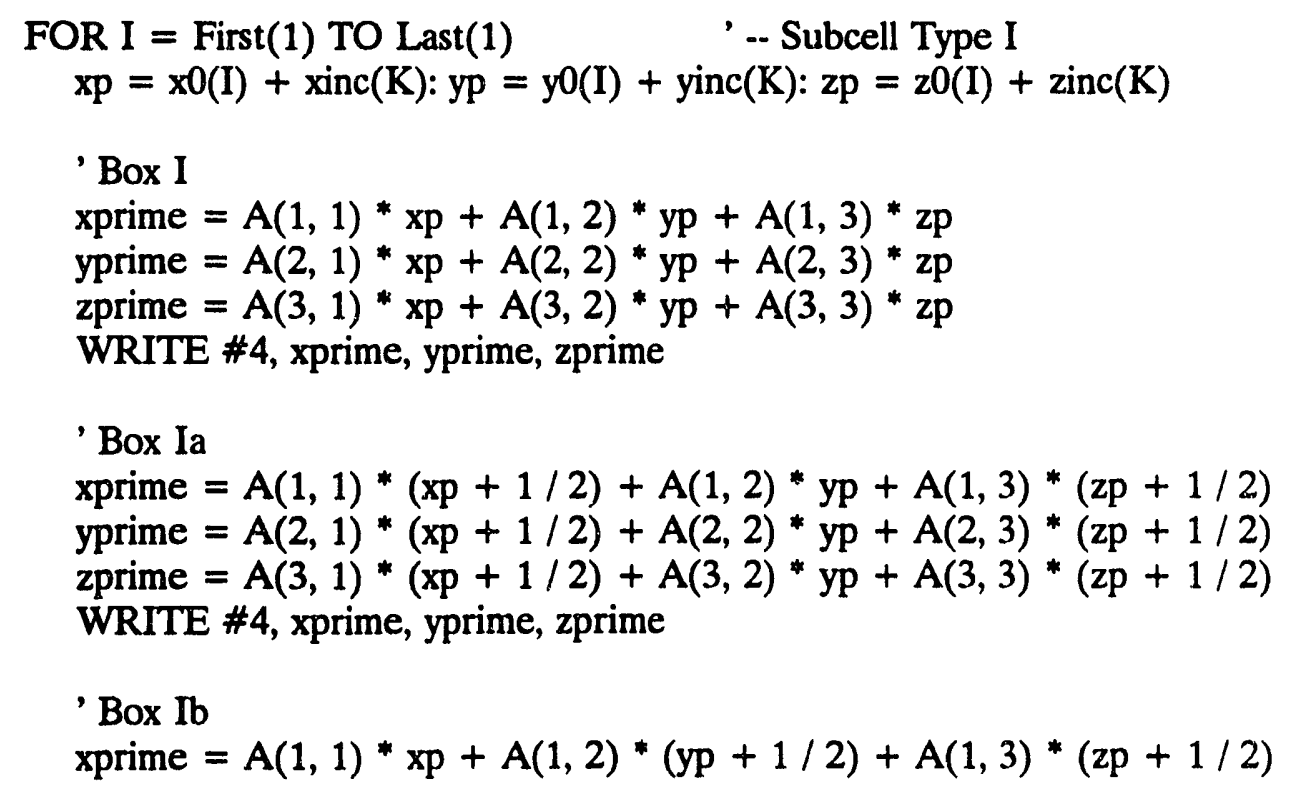


yprime $=A(2,1) * x p+A(2,2) *(y p+1 / 2)+A(2,3) *(z p+1 / 2)$

zprime $=A(3,1) * x p+A(3,2) *(y p+1 / 2)+A(3,3) *(z p+1 / 2)$

WRITE \#4, xprime, yprime, zprime

' Box Ic

"prime $=A(1,1) *(x p+1 / 2)+A(1,2) *(y p+1 / 2)+A(1,3) * z p$

yprime $=A(2,1) *(x p+1 / 2)+A(2,2) *(y p+1 / 2)+A(2,3) * z p$

zprime $=A(3,1) *(x p+1 / 2)+A(3,2) *(y p+1 / 2)+A(3,3) * z p$

WRITE \#4, xprime, yprime, zprime

\section{NEXT I}

' -- Calculations are done for 4 translations of the individual Type II subcell

'-- locations within the unit cell.

FOR I = First(2) TO Last(2) ' -- SubCell type II

$\mathrm{xp}=\mathrm{x} 0(\mathrm{I})+\operatorname{xinc}(\mathrm{K}): \mathrm{yp}=\mathrm{y} 0(\mathrm{I})+\operatorname{yinc}(\mathrm{K}): \mathrm{zp}=\mathrm{z} 0(\mathrm{I})+\mathrm{zinc}(\mathrm{K})$

- Box II

xprime $=A(1,1) * x p+A(1,2) * y p+A(1,3) * z p$

yprime $=A(2,1) * x p+A(2,2) * y p+A(2,3) * z p$

zprime $=A(3,1) * x p+A(3,2) * y p+A(3,3) * z p$

WRITE \#4, xprime, yprime, zprime

' Box IIa

xprime $=A(1,1) *(x p-1 / 2)+A(1,2) * y p+A(1,3) *(z p+1 / 2)$

yprime $=A(2,1) *(x p-1 / 2)+A(2,2) * y p+A(2,3) *(z p+1 / 2)$

zprime $=A(3,1) *(x p-1 / 2)+A(3,2) * y p+A(3,3) *(z p+1 / 2)$

WRITE $\# 4$, xprime, yprime, zprime

' Box IIb

xprime $=A(1,1) * x p+A(1,2) *(y p+1 / 2)+A(1,3) *(z p+1 / 2)$

yprime $=A(2,1) * x p+A(2,2) *(y p+1 / 2)+A(2,3) *(z p+1 / 2)$

zprime $=A(3,1) * x p+A(3,2) *(y p+1 / 2)+A(3,3) *(z p+1 / 2)$

WRITE \#4, xprime, yprime, zprime

'Box IIc

xprime $=A(1,1) *(x p-1 / 2)+A(1,2) *(y p+1 / 2)+A(1,3) * z p$ yprime $=A(2,1) *(x p-1 / 2)+A(2,2) *(y p+1 / 2)+A(2,3) * z p$ zprime $=A(3,1) *(x p-1 / 2)+A(3,2) *(y p+1 / 2)+A(3,3) * z p$ WRITE \#4, xprime, yprime, zprime

\section{NEXT I \\ NEXT K}

\section{CLOSE \#4}

'-- Read the transformed coordinates from the ASCII file into an array. 
Plot41\$ = "E:ATOMS.1"

OPEN Plot41\$ FOR INPUT AS \#4 LEN $=8$

Index $=1$

DO UNTIL EOF(4)

INPUT \#4, x0(Index), y0(Index), z0(Index)

Index $=$ Index +1

LOOP

CLOSE \#4

'-- Select unique transformed coordinates and output to the ASCII file.

' -- Prevents atoms with the same Y-Z coordinates from being output.

Plot41\$ = "E:ATOMS.1"

OPEN Plot $41 \$$ FOR OUTPUT AS \#4 LEN $=8$

WRITE \#4, y0(1), z0(1)

FOR I $=2$ TO Index

FOR $\mathrm{J}=1$ TO I - 1

IF $A B S(y 0(J)-y 0(I))<.00001$ THEN

IF ABS(z0(J) - z0(I)) $<.00001$ THEN

flag $=1$

END IF

END IF

NEXT J

IF flag $=0$ THEN

WRITE \#4, y0(I), z0(I)

END IF

flag $=0$

NEXT I

CLOSE \#4

END

' -- Routine to check if a point is within y-z limits specified within

' -- the y-z plane normal to the $x$-axis (i.e., the axial direction).

' -- To enable this option, enter limits below and replace starred section

' -- of code immediately above. $\mathrm{Y}$ and $\mathrm{Z}$ are the two axes of the Cartesian

' -- coordinate system normal to the crystal axis. Values are given as a

' -- multiple of the lattice spacing $a_{0}$.

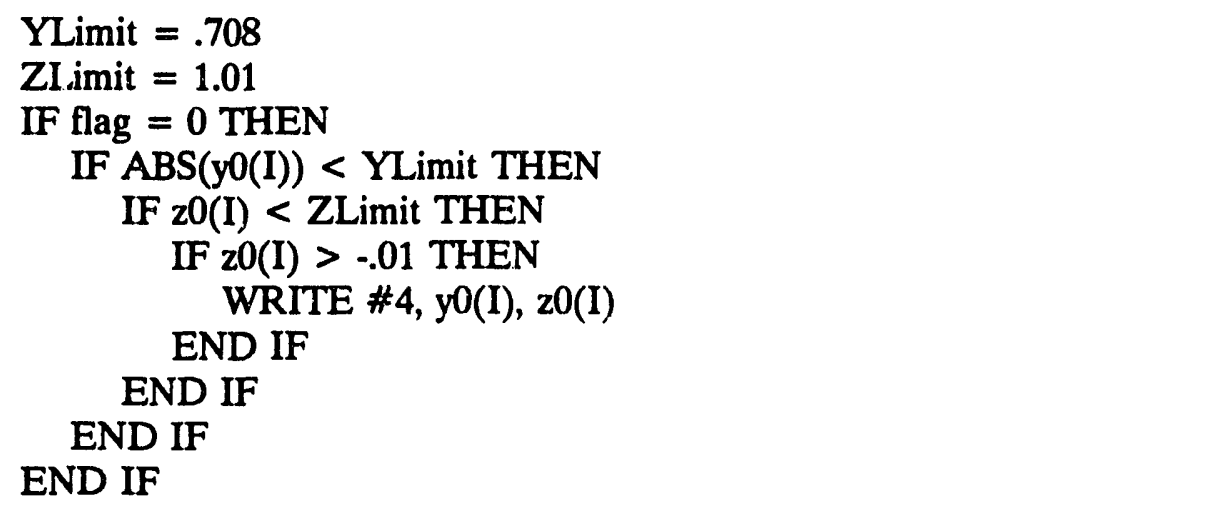


APPENDIX C

COMPUTER PROGRAM SECTION LISTING ATOM POSITIONS IN SPINEL 


\section{APPENDIX C}

\section{COMPUTER PROGRAM SECTION LISTING ATOM POSITIONS IN SPINEL}

Master List of Atomic Cartesian Coordinates for the Spinel Structure of $\mathrm{MgAl} 2 \mathrm{O} 4$.

'.- Values are given as a multiple of the lattice spacing $a_{0}$.

' -- Magnesium positinns - Type I SubCell

First(1) $=1: \operatorname{Last}(1)=4$

$\mathrm{x} 0(1)=0 \quad: \mathrm{y} 0(1)=0 \quad: \mathrm{z} 0(1)=0$

$\mathrm{x} 0(2)=0: \mathrm{y} 0(2)=1 / 2: \mathrm{zO}(2)=1 / 2$

$\mathrm{x} 0(3)=1 / 2: \mathrm{y} 0(3)=1 / 2: \mathrm{z} 0(3)=0$

$\mathrm{x} 0(4)=1 / 2: \mathrm{y} 0(4)=0 \quad: \mathrm{z} 0(4)=1 / 2$

' -- Aluminum positions - Type I SubCell

First(1) $=5:$ Last $(1)=8 \quad,(X 0, Y 0, Z 0)$ array subscript range

$\mathrm{x} 0(5)=3 / 8: \mathrm{y} 0(5)=1 / 8: \mathrm{z} 0(5)=1 / 8$

$\mathrm{x} 0(6)=1 / 8: \mathrm{y} 0(6)=3 / 8: \mathrm{z} 0(6)=1 / 8$

$\mathrm{x} 0(7)=1 / 8: \mathrm{y} 0(7)=1 / 8: \mathrm{z} 0(7)=3 / 8$

$\mathrm{x} 0(8)=3 / 8: \mathrm{y} 0(8)=3 / 8: \mathrm{zO}(8)=3 / 8$

'-- Oxygen positions - Type I SubCell

First(1) $=9: \operatorname{Last}(1)=12$

$\mathrm{x} 0(9)=1 / 8: \mathrm{y} 0(9)=1 / 8: \mathrm{z0}(9)=1 / 8$

$\mathrm{x} 0(10)=3 / 8: \mathrm{y} 0(10)=3 / 8: \mathrm{zO}(10)=1 / 8$

$\mathrm{x} 0(11)=3 / 8: \mathrm{y} 0(11)=1 / 8: \mathrm{z} 0(11)=3 / 8$

$\mathrm{x} 0(12)=1 / 8: \mathrm{y} 0(12)=3 / 8: \mathrm{z} 0(12)=3 / 8$

'-- Tetrahedral interstices - Type I SubCell

$$
\begin{aligned}
& \text { First }(1)=13: \text { Last }(1)=35 \quad \text { ' }(\mathrm{X} 0, \mathrm{Y} 0, \mathrm{Z0}) \text { array subscript range } \\
& \mathrm{x} 0(13)=0 \quad: \mathrm{y} 0(13)=0 \quad: \mathrm{z} 0(13)=1 / 4 \\
& \mathrm{x} 0(14)=0: \mathrm{y} 0(14)=0: \mathrm{zO}(14)=1 / 2 \\
& \mathrm{x} 0(15)=0: \mathrm{y} 0(15)=1 / 4: \mathrm{z0}(15)=0 \\
& \mathrm{x} 0(16)=0 \quad: \mathrm{yO}(16)=1 / 4: \mathrm{z} 0(16)=1 / 4 \\
& \mathrm{x} 0(17)=0 \quad: \mathrm{y} 0(17)=1 / 4: \mathrm{zO}(17)=1 / 4
\end{aligned}
$$




$$
\begin{aligned}
& \mathrm{x} 0(18)=0: \mathrm{y} 0(18)=1 / 2: \mathrm{z} 0(18)=0 \\
& \mathrm{x} 0(19)=0: \mathrm{y} 0(19)=1 / 2: \mathrm{z} 0(19)=1 / 4 \\
& \mathrm{x} 0(20)=1 / 4: \mathrm{y} 0(20)=0 \quad: \mathrm{z} 0(20)=0 \\
& \mathrm{x} 0(21)=1 / 4: \mathrm{y} 0(21)=0: \mathrm{z} 0(21)=1 / 4 \\
& \mathrm{x} 0(22)=1 / 4: \mathrm{y} 0(22)=0: \mathrm{z} 0(22)=1 / 2 \\
& \mathrm{x} 0(23)=1 / 4: \mathrm{y} 0(23)=1 / 4: \mathrm{z} 0(23)=0 \\
& \mathrm{x} 0(24)=1 / 4: \mathrm{y} 0(24)=1 / 4: \mathrm{z} 0(24)=1 / 4 \\
& \mathrm{x} 0(25)=1 / 4: \mathrm{y} 0(25)=1 / 4: \mathrm{z} 0(25)=1 / 2 \\
& \mathrm{x} 0(26)=1 / 4: \mathrm{y} 0(26)=1 / 2: \mathrm{z} 0(26)=0 \\
& \mathrm{x} 0(27)=1 / 4: \mathrm{y} 0(27)=1 / 2: \mathrm{z} 0(27)=1 / 4 \\
& \mathrm{x} 0(28)=1 / 4: \mathrm{y} 0(28)=1 / 2: \mathrm{z} 0(28)=1 / 2 \\
& \mathrm{x} 0(29)=1 / 2: \mathrm{y} 0(29)=0: \mathrm{z} 0(29)=0 \\
& \mathrm{x} 0(30)=1 / 2: \mathrm{y} 0(30)=0: \mathrm{z} 0(30)=1 / 4 \\
& \mathrm{x} 0(31)=1 / 2: \mathrm{y} 0(31)=1 / 4: \mathrm{z} 0(31)=0 \\
& \mathrm{x} 0(32)=1 / 2: \mathrm{y} 0(32)=1 / 4: \mathrm{z} 0(32)=1 / 4 \\
& \mathrm{x} 0(33)=1 / 2: \mathrm{y} 0(33)=1 / 4: \mathrm{z} 0(33)=1 / 2 \\
& \mathrm{x} 0(34)=1 / 2: \mathrm{y} 0(34)=1 / 2: \mathrm{z} 0(34)=1 / 4 \\
& \mathrm{x} 0(35)=1 / 2: \mathrm{y} 0(35)=1 / 2: \mathrm{z} 0(35)=1 / 2
\end{aligned}
$$

'-- Magnesium positions - Type II SubCell

First $(2)=36: \operatorname{Last}(2)=40$ $\mathrm{x} 0(36)=3 / 4: \mathrm{y} 0(36)=1 / 4: \mathrm{z} 0(36)=1 / 4$ $\mathrm{x} 0(37)=1 / 2: \mathrm{y} 0(37)=1 / 2: \mathrm{z} 0(37)=0$

$\mathrm{x} 0(38)=1 / 2: \mathrm{y} 0(38)=0 \quad: \mathrm{z} 0(38)=1 / 2$

$\mathrm{x} 0(39)=1 \quad: \mathrm{y} 0(39)=1 / 2: \mathrm{z} 0(39)=1 / 2$

$\mathrm{x} 0(40)=1: \mathrm{y} 0(40)=0 \quad: \mathrm{zO}(40)=0$

\section{'-- Oxygen positions - Type II SubCell}

First $(2)=41:$ Last $(2)=44$ $\mathrm{x} 0(41)=5 / 8: \mathrm{y} 0(41)=1 / 8: \mathrm{z} 0(41)=1 / 8$ $\mathrm{x} 0(42)=7 / 8: \mathrm{y} 0(42)=3 / 8: \mathrm{z} 0(42)=1 / 8$ $\mathrm{x} 0(43)=5 / 8: \mathrm{y} 0(43)=3 / 8: \mathrm{z} 0(43)=3 / 8$ $\mathrm{x} 0(44)=7 / 8: \mathrm{y} 0(44)=1 / 8: \mathrm{zO}(44)=3 / 8$

' -- Octahedral interstices - Type II SubCell

First(2) $=45:$ Last $(2)=48 \quad$ ' (X0, Y0, Z0) array subscript range $\mathrm{x} 0(45)=7 / 8: \mathrm{y} 0(45)=1 / 8: \mathrm{z0}(45)=1 / 8$ $\mathrm{x} 0(46)=7 / 8: \mathrm{y} 0(46)=3 / 8: \mathrm{z} 0(46)=3 / 8$ $\mathrm{x} 0(47)=5 / 8: \mathrm{y} 0(47)=3 / 8: \mathrm{z} 0(47)=1 / 8$ $\mathrm{x} 0(48)=5 / 8: \mathrm{y} 0(48)=1 / 8: \mathrm{z} 0(48)=3 / 8$

' -- Tetrahedral interstices - Type II SubCell 


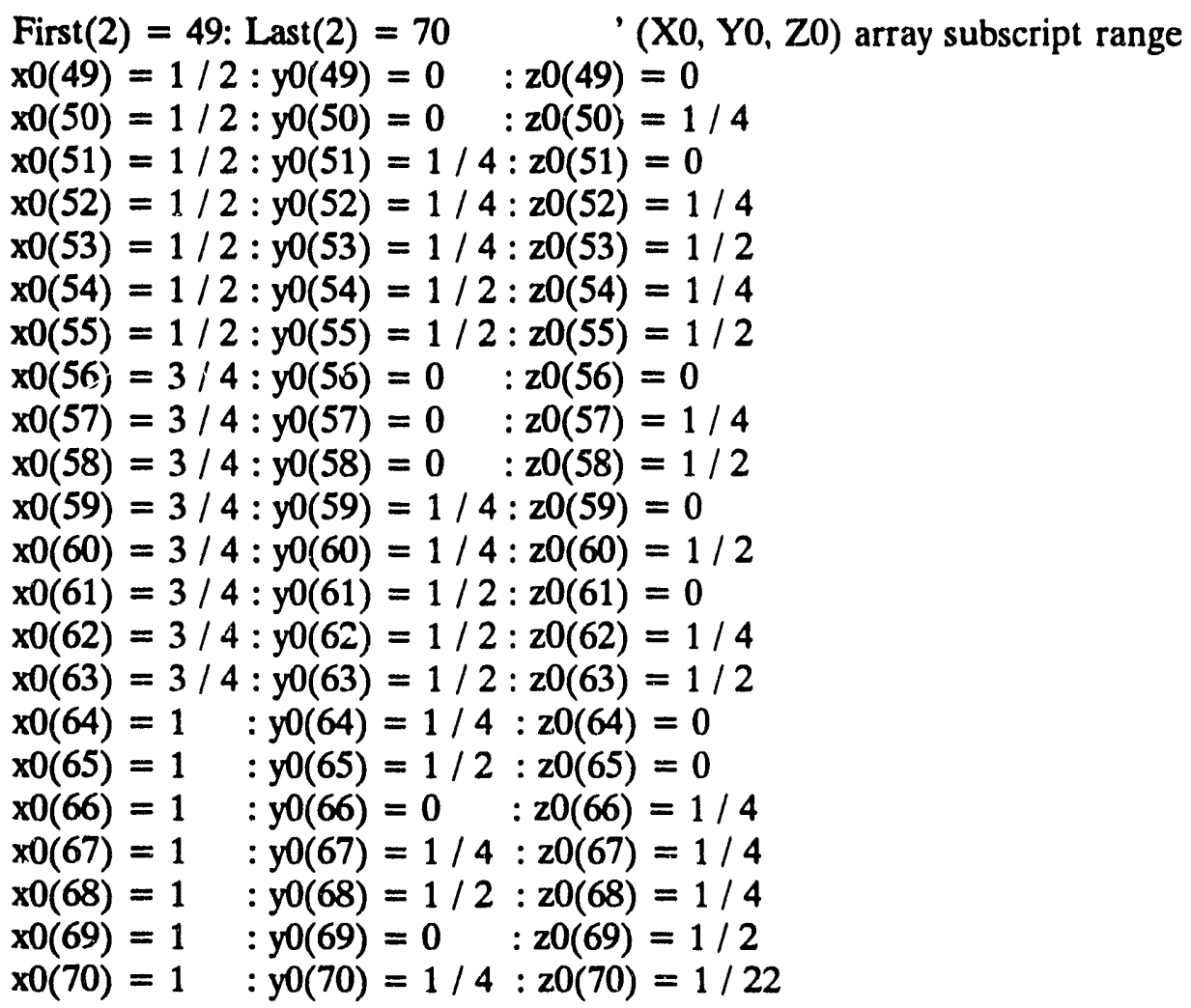


ORNL/TM-12170

Dist. Category UC-25

\section{INTERNAL DISTRIBUTION}

112. Central Research Library

3. Document Reference Section

4-5. Laboratory Records Department

6. Laboratory Records, ORNL RC

7. ORNL Patent Section

8-10. M\&C Records Office

11. K. B. Alexander

12-16. W. R. Allen

17. B. R. Appleton

18. R. A. Buhl

19. L. L. Horton

20. T. M. Kinney

21. E. H. Lee

22. M. B. Lewis

23. C. T. Liu
24. G. M. Ludkta

25. L. K. Mansur

26. R. C. Martin

27. S. D. Nunn

28. D. F. Pedraza

29. C. W. White

30. J. M. Williams

31. S. J. Zinkle

32. Y. A. Chang (Consultant)

33. H. W. Foglesong (Consultant)

34. J. J. Hren (Consultant)

35. M. L. Savitz (Consultant)

36. J. G. Simon (Consultant)

37. K. E. Spear (Consultant)

\section{EXTERNAL DISTRIBUTION}

38. DOE, OAK RIDGE FIELD OFFICE, P. O. Box 2001, Oak Ridge, TN 37831-8600 Assistant Manager for Energy Research and Development

39-40. DOE, OFFICE OF SCIENTIFIC AND TECHNICAL INFORMATION, Office of Information Services, P. O. Box 62, Oak Ridge, TN 37831

For distribution by microfiche as shown in DOE/OSTI-4500

Distribution Category UC-25 (Materials). 

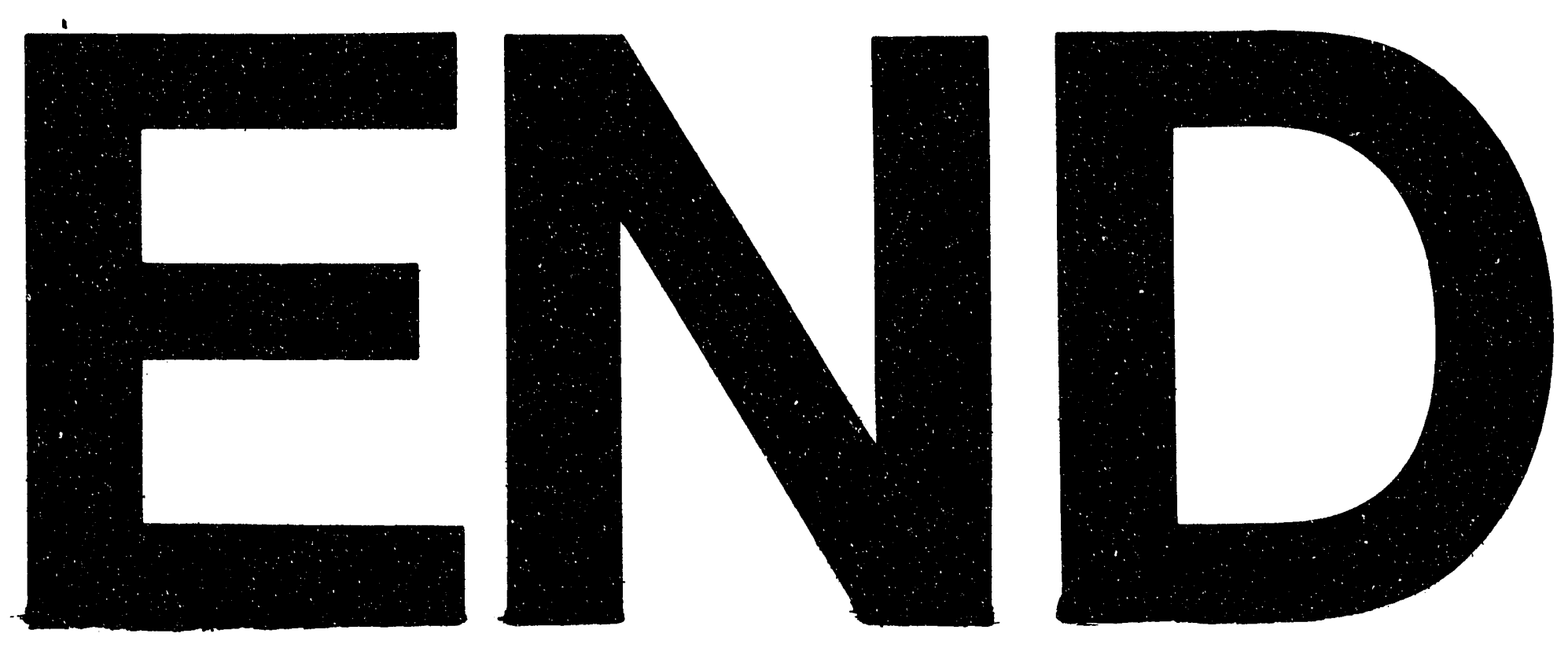

28

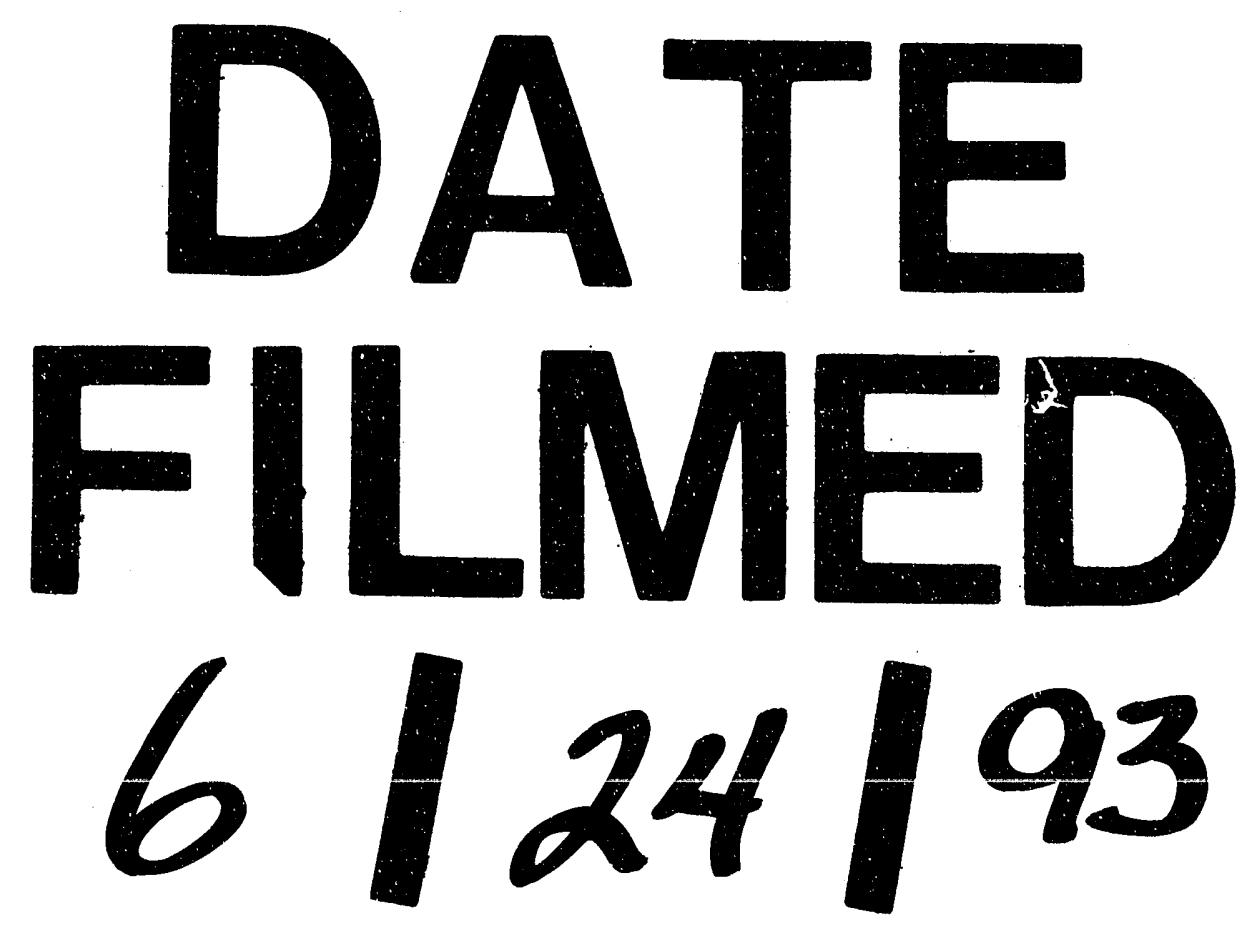


